\title{
The Relationship Of Infest Proportion With Types And Reaction On Lepsory Patient In The Regional Hospital Of Dr. Zainoel Abidin Banda Aceh
}

\author{
Wahyu Lestari ${ }^{1}$, Sulamsih $^{2}$, Mauliza $^{3}$, Nur Fardian $^{4}$ and Alhuda $^{5}$ \\ \{wahyu_lestari2000@yahoo.com\} \\ ${ }^{1,2}$ Department of DermatoVenereology,Universitas SyiahKuala,Aceh,Indonesia \\ ${ }^{3}$ Department of Medical Sciences, Universitas Malikussaleh, Aceh, Indonesia \\ ${ }^{4}$ Department of Nutrition, Universitas Malikussaleh, Aceh, Indonesia \\ ${ }^{5}$ Department of Health Nursing, Akademi Keperawatan Kesdam Iskandar Muda, Lhokseumawe, \\ Indonesia
}

\begin{abstract}
Leprosy is a chronic disease caused by the bacteria Mycobacterium leprae that attacks the nervous, skin, mucosa (mouth) organs, upper respiratory tract, endothelial reticulocyte system, eyes, muscles, bone and testis. Infections of worms are associated with leprosy comorbidities, it may affect disease travel and immunoregulation process and disease metabolism including leprosy, so breed leprosy and leprosy reaction. To know more about worms in leprosy patients and withleprosy and leprosy reactions. The diagnosis is based on history, physical examination, smear examination/smear skin cleft and faecal examination. This research is using cross sectional method, and the statistical analysis with chi square test. The results of the study over 22 subjects were found male patients more $12(54.5 \%)$, and there are more MB type patients around 17 patients $(77.3 \%)$. Patients with a history of 14 white ENL reactions $(63.6 \%)$ are greater than without reactions. The onset of reaction, patients during MDT treatment were more that 8 patients $(57.1 \%)$ compare to before and after MDT treatment. The parasite was found in $2 \mathrm{MB}$ leprosy patients with ENL reaction with positive parasite results ie Ancylostoma Duodenale and Trichuris Trichiura.
\end{abstract}

Keywords: Worm infestation, Leprosy Reaction, Leprosy Patient, RSUDZA

\section{INTRODUCTION}

Leprosy is an infectious disease caused by Mycobacterium leprae. Clinically a leprosy is consists of several spectra that depend on the patient's immune response. Leprosy attacks many societies with low socioeconomic conditions. This condition is associated with poor nutrition and result in lower body immunity in general. Environmental factors and poor hygiene are always found in patients infected with M. leprae. 1-2 Factors to consider in leprosy patients are the pathogenesis of disease, mode of transmission, socioeconomic and environmental conditions, genetics related to susceptibility, immune change, and the possibility of reservoirs outside of humans. The pathogenesis of leprosy is influenced by 
the immune response to M.leprae both in determine the type of leprosy or the development or absence of the disease. $\mathrm{T}$ cells and macrophages play an important role in the process of recognition and response to $M$. leprae antigen.1-3 One of the infections associated with leprosy comorbidities is the infection of the worms. This infection is one of the highest endemic and chronic diseases in Indonesia and the case rises sharply during the rainy season and the flood. The worms enter the body in the larval phase and spread to various places to invade the human body.

From the latest research found that worm infections can affect the course of disease and immunoregulation process and metabolism of diseases including leprosy. The spectrum of leprosy is affected by the body's response to M. leprae bacteria, so that worm infections in the body can affect the clinical manifestations of leprosy and leprosy reactions.

\section{RESEARCH METHOD}

The purpose of this research is to know the proportion of worm infestation in leprosy patients. Place and time of research of Skin and Gender of Regional Hospital (RSUZA), Banda Aceh, March 2017 until August 2017.

The population in this study is leprosy patients who came to the Skin and Gender RSUZA Clinic, Banda Aceh. Inclusion criteria: lepers aged 18-60 years old, new or moderate patients receiving MDT treatment, and signed informed concent. Exclusion criteria: patients receiving medication other than MDT have received anti-worming medication in the past 3 months, or have received laxatives/saline hypertonic in the last 14 days and suffer from severe systemic diseases such as HIV, tuberculosis. The patient research procedure consists of: identity, anamnesis, and clinical data, type of leprosy, smear examination and faecal examination. Stool examination: each patient is taken at least 1 gram, which then performed direct smear examination and sedimentation to get the worm parasite.

The patient control was performed every 2 weeks during the 3 -month study period. Clinical evaluation at the end of the study was made according to clinical criteria. At the end of the study there were clinical evaluations and documentary photographs. At each visit all clinical abnormalities were noted.

\section{RESEARCH RESULT}

This research was conducted at the regional hospital RSUDZA, Banda Aceh. The population of this study was all patients with leprosy. Worm infection is one of the comorbid infections that can be found in Hansen's morbus (MH) patient. This current research has shown that worm infections can affect various travel diseases through their effects on immunoregulation and metabolic processes. The clinical spectrum of $\mathrm{MH}$ has been known to rely heavily on host immune responses to M. Leprae bacteria, so intestinal helminth infection is also suspected to have a role in clinical manifestation of $\mathrm{MH}$ and erythema nodosum leprosum (ENL) reactions. Leprosy can affect humans in both sexes, male and females, but some types of males tend to be more common than women. The number of male patients is more likely to be more women than women, and it is associated with greater sexual activity in larger urban areas.

From the results of the study found that there are still many patients with leprosy who do not want to seek treatment to the hospital with a variety of reasons. So, the early handling is 
not maximal. Those all description above could be the main source of Leprosy transmission is human. Leprosy bacteria are nested in the skin and mucosa of the human nose. Leprosy bacteria have an incubation period of 2 - 5 years can even take more than 5 years. Not yet known exactly how the transmission of leprosy germs. Theoretically, a person is infected with a leprosy germ since they have been in direct contact for a very long time with people affected by leprosy who have not taken the medicine. Moreover, the indication of the infaction over the leprosy germs to others is estimated through the upper respiratory tract.

Table 1. Demography Overview of the Leprosy Patient during May - July 2017

\begin{tabular}{|c|c|c|c|c|}
\hline \multirow{2}{*}{ No. } & \multirow{2}{*}{$\begin{array}{c}\text { Demography } \\
\text { Overview }\end{array}$} & \multicolumn{2}{|c|}{ Leprosy Type n (\%) } & \multirow{2}{*}{$\begin{array}{l}\text { Total } \\
\mathrm{n}(\%)\end{array}$} \\
\hline & & $\begin{array}{c}\text { Paucibasiler (PB) } \\
(\mathrm{n}=5)\end{array}$ & $\begin{array}{c}\text { Multibasiler (MB) (n } \\
=17)\end{array}$ & \\
\hline \multirow[t]{3}{*}{1} & Gender & & & \\
\hline & - Male & 3 & 9 & $12(54,5)$ \\
\hline & - Famale & 2 & 8 & $10(45,5)$ \\
\hline \multirow[t]{4}{*}{2} & Age & & & \\
\hline & - $\quad 18-29$ year & 2 & 9 & $11(50)$ \\
\hline & - $30-44$ year & 2 & 7 & $9(40,9)$ \\
\hline & - $\quad 45-60$ year & 1 & 1 & $2(9,1)$ \\
\hline \multirow[t]{6}{*}{3} & Education & & & \\
\hline & - SD & 0 & 3 & $3(13,6)$ \\
\hline & - SMP & 1 & 6 & $7(31,8)$ \\
\hline & - SMU & 3 & 4 & $7(31,8)$ \\
\hline & - $\quad \mathrm{S} 1$ & 1 & 4 & $5(22,8)$ \\
\hline & $-\quad \mathrm{S} 2-\mathrm{S} 3$ & 0 & 0 & $0(0,00)$ \\
\hline
\end{tabular}

Regarding to the Table 1 it is known that the number of male patients is 12 patients or $54.5 \%$, while female is 10 patients or $45.5 \%$. By age group, patients with age group 18 to 29 years were 11 people or $50 \%$, age group 30 to 44 years were 9 patients or $40.9 \%$, and the age group 45 to 60 years were 2 patients or $9.1 \%$. Based on the level of education, patients with elementary school education amounted to 3 patients or $13.6 \%$, junior high school education amounted to 7 patients or $31.8 \%$, high school education amounted to 7 patients or $31.8 \%$, and education $\mathrm{S} 1$ amounted to 5 patients or $22.8 \%$.

This is consistent with the previous study conducted by Lukas et al., that uncovered the most age groups in the 30-39 year age range of 35 people $(22.2 \%)$ and the male sex of 108 $(68.4 \%)$ compared to women 50 people (31.6\%).(20) Epidemiological studies in India reported National Institute of Epidemiology states leprosy is more common in men $(58 \%)$ than females (42\%).(21) Phillips DA, Rio dejainero reported that cases of leprosy type MB more commonly found that is $76 \%$, with an average age of 48 years and men more than women.(22) As one of the factors penyularankusta, men tend to work more than women. Halini is closely related to the customs, where the man as the head of the family is demanded to be able to work to meet the needs of his family. However, as the development of the matter is little by little changed in because there are many women who now become the backbone of his family.

Leprosy is closely related to the factors of knowledge (education). Where the incidence of leprosy is more common in patients who have low knowledge about leprosy.Because of ignorance then they do not immediately seek or check themselves. The period before the 
treatment is a moment prone to spread leprosy to others. This is what usually triggers the increase of new sufferers in an area that result in the loss of leprosy in society.

Table 2. Clinical Features of Leprosy Patients

\begin{tabular}{|c|c|c|c|}
\hline No. & Clinical Overview & $\mathrm{n}$ & Percentage (\%) \\
\hline 1 & $\begin{array}{l}\text { Leprosy Type } \\
-\quad \mathrm{PB} \\
\text { - } \mathrm{MB}\end{array}$ & $\begin{array}{c}5 \\
17\end{array}$ & $\begin{array}{l}22,7 \\
77,3\end{array}$ \\
\hline 2 & $\begin{array}{l}\text { Medical Treatment History } \\
\text { - } \quad \text { MDT }- \text { WHO Treatment } \\
\text { - } \quad \text { RFT } \leq 6 \text { Months } \\
\text { - } \quad \text { RFT }>6 \text { Months }-1 \text { Year }\end{array}$ & $\begin{array}{c}12 \\
4 \\
6\end{array}$ & $\begin{array}{l}54,5 \\
18,2 \\
27,3\end{array}$ \\
\hline 3 & $\begin{array}{l}\text { Reaction History } \\
\text { - Without reaction ENL } \\
\text { - Reaction ENL }\end{array}$ & $\begin{array}{c}8 \\
14\end{array}$ & $\begin{array}{l}36,4 \\
63,6\end{array}$ \\
\hline 4 & $\begin{array}{l}\text { Onset Reaction } \\
\text { - } \quad \text { Before Treatment MDT - WHO } \\
\text { - } \quad \text { During Treatment MDT - WHO } \\
\text { - } \quad \text { After Treatment MDT - WHO }\end{array}$ & $\begin{array}{l}4 \\
8 \\
2\end{array}$ & $\begin{array}{l}28,6 \\
57,1 \\
14,3\end{array}$ \\
\hline 5 & $\begin{array}{l}\text { Treatment duration of Kostecosteroid Reaction } \\
-\quad \leq 12 \text { Months } \\
-\quad>12 \text { Months }\end{array}$ & $\begin{array}{c}14 \\
0\end{array}$ & $\begin{array}{r}100 \\
0\end{array}$ \\
\hline
\end{tabular}

The number of patients with PB type leprosy is 5 patients or $22.7 \%$, while the MB type is 17 patients or $77.3 \%$. On the be half of the history of treatment, patients in MDT-WHO treatment were 12 patients or $54.5 \%$, treatment history of RFT $\leq 6$ months was 4 patients or $18.2 \%$, and treatment history of RFT $>6$ months - 1 year was 6 patients or $27.3 \%$. regarding to reaction, patients with ENL reaction amounted to 14 patients or $63.6 \%$, whereas without ENL reaction was 8 patients or $36.4 \%$. Additionally, the onset of reactions, patients before treatment of MDT - WHO were 4 patients or $28.6 \%$, during treatment of MDT - WHO was 8 patients or $57.1 \%$, and after treatment MDT - WHO 2 patients or $14.3 \%$. Beside, in term of the duration of treatment, patients with treatment duration greater than or equal to 12 months amounted to 14 patients.

The finding is supporting the prior research by Oktarina et al., they found that the most reaction types of $\mathrm{MB}$ as many as 61 people (75.3\%) and $\mathrm{PB}$ as many as 20 people (24.7). (24) Then, direct contact with patients either skin contact between families, neighbors or friends is the main source of transmission between humans. In general, both in terms of age and sex, people with MB leprosy type (MultiBasiler) have a risk of passing the bacterial by physical contact to others by fifth to eight times compared with two times only PB (Pausi Basiler) .

World Health Organization (WHO) recommends the MDT regimen with duration of six months for patients who produce prostatic and lupus punctures for patients with multibacillary 
leprosy. These regimens are effective for the eradication of M. valves to leprosy patients. The treatment may take longer if some patients have high bacterial indexes to prevent relapse.

Table 3. The overview of Leprosy Patient With Positive Parasite Results ( $\mathrm{n}: 2$ )

\begin{tabular}{cccccc}
\hline No. & Leprosy Type & & Parasite & Infection Intensity & Amount \\
\hline 1 & MB & MB & Ancylostoma Duodenale & Weight & $20 \mathrm{egg} / \mathrm{gr}$ \\
2 & MB & MB & Trichwris Trichiwra & Weight & $16 \mathrm{egg} / \mathrm{gr}$ \\
Total & & 2 & & & \\
\hline
\end{tabular}

From the Table 3 above, there are 22 subjects were obtained 2 patients with MB leprosy with ENL reaction and positive parasite result that is Ancylostoma Duodenale and Trichuris Trichiura. Phillips DA, Rio dejainero, 2017 reported that worm infections can affect the transmission of leprosy in endemic areas. Lukas et al., also reported that from his research, the infestation of Hemoglobacteric nematodes was 1 (1.4\%) and multibasiler MH 72 people (98.6\%). The subjects of the study were 36 peoples $(42.4 \%)$ and multibacillary MH 49 people (57.6\%). (22) Diniz et al., conducted the previous study in Brazil which state the frequency of infestation of worms is worse than that of the MH multibaciller patients compared with the pausibasiler. $(25,26)$ Prost's study, et al., Reveals the prevalence of intestinal worm infestation of nematodes found in multibacillary MH. (25) In leprosy patients with frequent reactions, protozoan and intestinal parasites. The most common protozoa are E. Histolytica (25\%), G.lamblia (8\%), whereas the most common parasites are A.duodenale, S. Stercoralis and H.nana.

Table 4. An Overview of Leprosy Patients With Parasitic Infections

\begin{tabular}{lcccc}
\hline & $\begin{array}{c}\text { Negative Parasite } \\
\text { Infection (\%) }\end{array}$ & $\begin{array}{c}\text { Positive Parasite } \\
\text { Infection }(\%)\end{array}$ & $\begin{array}{c}\text { Total n } \\
(\%)\end{array}$ & p value \\
\hline Pausibasiler & 5 & 0 & $5(22,7)$ & 1,000 \\
Multibasiler & 15 & 2 & $17(77,3)$ & \\
$\quad$ Total & 20 & 2 & $22(100)$ & \\
\hline ENL Reaction & 1 & 2 & $14(63,6)$ & 0,515 \\
Without ENL & 8 & 0 & $8(36,4)$ & \\
Reaction & 20 & 2 & $22(100)$ & \\
\multicolumn{1}{c}{ Total } & & & & \\
\hline
\end{tabular}

This research uses chi square test, as showed in table 4 , it is stated that p-value value for testing the relationship between leprosy type with parasitic infestation is 1,000 >0,05, which means that there is no relationship between leprosy type and infestation parasite.

Based on the result of Chi Square test, the p-value for testing the correlation between reaction history with parasite infestation is $0,515>0,05$, meaning that there is no correlation between reaction history with parasitic infestation. 
Singh SK, et al., performed a study in Nepal 2015, they found that from 200 patients with reactions and non-leprosy reactions obtained $33 \%$ protozoa ie 5.5\% Trichomonas hominis worms, Strongyloides stercoralis and Ancylostoma duodenale in leprosy patients with reactions. There is a relationship between intestinal parasite co-infection and leprosy. (28) Octaria, et al. Reported from 81 leprosy patients found 11 patients with parasitic infections namely Trichuris trichiura mild degree in 5 patients and severe stercoralis Strongyloides in 6 patients. Wherein there may be a correlation between worm infection and leprosy severity.

In this study the results obtained were very low in only $2 \mathrm{MB}$ leprosy patients with ENL reaction with parasitic infestations Ancylostoma Duodenale and Trichuris Trichiura. Although the results of statistical test analysis there is no relationship between parasite infestation with the type and leprosy reaction, but parasitic infestations obtained need to be observed to determine the progression of the disease.

\section{CONCLUSION}

Leprosy is also known as Lepros disease or Hansen Disease which in history note that this disease has been known to the public since $300 \mathrm{BC}$. This disease is a chronic infection caused by Mycobacterium Leprae bacteria. The bacterium was first discovered by G.A. Hansen in 1873. This bacterium undergoes a process of division long enough between 2 - 3 weeks. Life survival of leprosy germs reaches 9 days outside the human body.

The main source of Leprosy transmission is human. Leprosy bacteria are nested in the skin and mucosa of the human nose. Leprosy bacteria have an incubation period of 2 - 5 years can even take more than 5 years. Not yet known exactly how the transmission of leprosy germs. However, it is theoretically known that a person is infected with leprosy bacteria because it has been in direct contact for a very long time with people affected by leprosy who have not taken the medicine.

This is a preliminary study and the results of this study show that parasitic infestation does not play a role with leprosy type and reactions. However, further research is needed with a larger number of patients and a longer period of study to determine the role of parasitic infestation in leprosy patients, although the role of parasite infestation is unclear in influencing the progression of leprosy type and reactions.

\section{References}

[1] J. Smith, The book, 2nd ed. London: The publishing company, 1998.

[2] M. Singh, S.K. and Maharjan, . "Intestinal Parasitic Co-Infection in Reaction and NonReaction Leprosy Patients of Dhanusha, Nepal,” J. Inst. Sci. Technol., vol. 20, no. 1, pp. 64-67, 2015.

[3] J. . Phillips, D.A., Ferreira, J.A., Ansah, D., Teixeira, H.S., Kitron, U., Filippis, T.D., de Alcântara, M.H. and Fairley, "A tale of two neglected tropical infections: using GIS to assess the spatial and temporal overlap of schistosomiasis and leprosy in a region of Minas Gerais, Brazil," Mem. Inst. Oswaldo Cruz, vol. 112, no. 4, 2017.

[4] E. . Oktaria, S., Effendi, E.H., Indriatmi, W., van Hees, C.L., Thio, H.B. and SjamsoeDaili, "Soil-transmitted helminth infections and leprosy: a cross-sectional study of the association between two major neglected tropical diseases in Indonesia," BMC Infect. Dis., vol. 16, no. 1, p. 258, 2016. 
[5] National Institute of Epidemiology, "WHO international multi-centric study on uniform MDT 9 regimen for all typesof leprosy patients.," 2005.

[6] A. . Manyullei, S., Utama, D.A. and Birawida, "Gambaran faktor yang berhubungan dengan penderita kusta di Kecamatan Tamalate Kota Makassar," Arch. Community Heal., vol. 1, no. 1, pp. 10-17, 2012.

[7] S. Tjekyan, "Hubungan Peningkatan Interleukin-10 Akibat Infestasi Cacing Usus Nematoda terhadap Spektrum Morbus Hansen," Majalah Kedokteran Sriwijaya, 2015.

[8] K. S. Wolff K, Goldsmith LA, Fitzpatricks Dermatology in general medicine. 2012.

[9] Kementerian Kesehatan RI Direktorat Jenderal Pengendalian Penyakit Dan Penyehatan Lingkungan, "Pedoman Nasional Program Pengendalian Penyakit Kusta," 2012.

[10] R. Diniz, L.M., Magalhães, E.F., Pereira, F.E., Dietze, R. and Ribeiro-Rodrigues, "Presence of intestinal helminths decreases $\mathrm{T}$ helper type 1 responses in tuberculoid leprosy patients and may increase the risk for multi-bacillary leprosy," Clin. Exp. Immunol., vol. 161, no. 1, pp. 142-150, 2010.

[11] R.-R. R. Diniz LM, Zandonade EL, Dietze RE, Pereira FE, “do intestinal nematodes increase the risk for multibacillary leprosy?," Am. J. Trop. Med. Hyg., vol. 65, no. 6, pp. 852-856, 2001.

[12] C. L. Anthony Bryceson, Roy E. Pfaltzgraff, Medicine in the tropic. 1990. 